\title{
PECKING AND SCRATCHING IN THE DEVELOPMENT OF DUST PERCEPTION IN YOUNG CHICKS
}

\author{
K. S. VESTERGAARD', E. BARANYIOVÁ2 \\ ${ }^{1}$ The Royal Veterinary and Agricultural University, Department of Animal Science and Animal Health, 13 \\ Bülowsvej, DK-1870 Frederiksberg, Denmark \\ ${ }^{2}$ Department of Biochemistry, University of Veterinary and Pharmaceutical Sciences, 61242 and Veterinary \\ Research Institute, 62132 Brno, Czech republic
}

Received July 31, 1995

Accepted June 6. 1996

\begin{abstract}
Vestergaard K. S., E. B a ra n y i ová: Pecking and Scratching in the Development of Dust Perception in Young Chicks. Acta vet. Brno 1996, 65:133-142.

The aim of the study was to examine the possibility that early pecking and scratching experiences by a chick may influence its dustbathing later in life. Pecking experience was controlled in pairs of chicks housed in wire cages by presentation of peat or sand from small boxes. In experiment 1 ( 12 pairs) 5 min tests were carried out on days 3-9 and 16-17, whereas on days 1015 we allowed the chicks to peck for $30 \mathrm{~min}$ in order to elicit dustbathing on a glassplate. Finally, a dustbathing choice test, in which the chicks were allowed full access to dustbathe in the substrates, was carried out on days 16-19. In experiment 2.8 pairs were given 2 min pecking experience, and 8 pairs 10 min of pecking experience with sand on day 5-9. and all pairs were given 5 min pecking experience on days 3 and 4 ; the birds were then tested for dustbathing on days 10-15, as in experiment 1 . In experiment 1, pecking at peat increased from day 3 to 9 and peat was preferred over sand. The amount of pecking at either or both substrates was examined for correlation with later dustbathing performance towards these substrates, and, generally, a positive and significant correlation was found between pecking at peat on day 3 , and dustbathing on the glass (day 10-15) as well as with dustbathing in the substrates during the dustbathing choice tests. Furthermore, a regression analysis revealed that the amount of total pecking on day 3-9 was associated with increased dustbathing on days 10-15. Scratching during the 5 min pecking tests was positively correlated with pecking except for scratching while pecking at peat on days $16+17$. Scratching on days $16+17$ while pecking at sand, but not at peat, was positively correlated with dustbathing directed towards sand (30 min tests) and in sand during the dustbathing choice tests.

In experiment 2, the chicks that were given most pecking experience on day 5-9 tended to dustbathe more during the 30 min tests day on 10-15.

In conclusion, early pecking (day 3-5) at dusty substrates was related to later dustbathing and may be significant for the development of dust perception in young chicks. whereas scratching while pecking at sand became related to dusthathing in sand after day 10-15.
\end{abstract}

Gallus domesticus, peat. sand. behaviour, development

In this study we examine the possibility that the early pecking and scratching experiences by a chick may influence its dustbathing later in life. Dustbathing behaviour in chicks starts to develop by day 4 of life ( $\mathrm{K} \mathrm{ru} \mathrm{ij} \mathrm{t} \mathrm{1964)} \mathrm{but} \mathrm{already} \mathrm{by} \mathrm{day} 1$ young chicks easily respond to the presentation of dusty substrates; they explore them by pecking and scratching (ground scratching with a leg), and the substrates are often swallowed (Hog a n 1971). When kept in a barren environment and allowed to peck at dust substrates, such as sand, earth and peat, young chicks may start bill-raking in the substrates and then scratching, and eventually perform vertical wing-shaking and other dustbathing behaviour elements (see $\mathrm{Kruijt}$ 1964) on the wire floor after a period of initial intensive pecking and swallowing (Vesterga ard and $\mathrm{Hog}$ an 1992). It has also been shown that early pecking preferences on day 2-7 were related to later dust preferences in domestic chicks ( $\mathrm{S}$ a n o $\mathrm{r}$ a et al. 1995). All this clearly indicates a link between pecking at such substrates and dustbathing 
behaviour. at least at this stage of development. Pecking (and maybe scratching), therefore, may play a significant role in the development of dust perception in chicks. Visual stimuli may also be significant. and the perception of them may have developed prefunctionally because experience is not necessary for the expression of the preference (Pe the rick et al. 1995).

In this study we further examine the association between early pecking (and scratching) and the development of the perceptual mechanism of the dustbathing behaviour system with the aim to reveal the sensitive period of dust "imprinting" in fowl.

\section{Materials and Methods}

Animals and housing

In experiment 1. we used 24. and in experiment 2. 32 male chicks (Lohman Selected Leghorn) that were provided from a commercial breeder on the day of hatching. After transport to the laboratory the birds of each experiment were randomly allocated as pairs in small wire cages (see Vesterga ard et al. 1990).

The cages $(4.5 \times 4.5 \times 45 \mathrm{~cm})$ had masonite backsides and sides, to prevent visual contact between neighbouring pairs. Ceilings, fronts and floors were made of wire mesh $(1 \times 3 \mathrm{~cm})$. Light was on from $0700 \mathrm{hr}$ until $1900 \mathrm{~h}$. In each cage a granulated diet was provided from a cylindrical feeder with a small opening to prevent birds from dusthathing in the food, and water was provided from small water cylinders. One of the chicks in each cage was marked with black specd-marker on the head. See Vesterga ard and Lisborg (1993) for further details.

\section{Experimental procedures}

In experiment 1.5 min peching tests were carried out on day 3-9 and then again on day 16 and 17 . A small metal box. $6 \times 18 \times 3.5 \mathrm{~cm}$ that had three separate and equally large spaces was used for the simultaneous presentation of sifted peat and yellow very fine grained sand from Æro island. Denmark. The sand and peat were placed in the two side spaces whereas the central space was empty and covered by wire to avoid mixing of the substrates. On day 3 9 a glassplate $(20 \times 13 \mathrm{~cm})$ was placed during half of the tests under the box and extending behind it so that chicks that pecked the substrates would scratch the glass if they scratched during the test. Half of the pairs started on the first day with the glass present and over the days each pair alternately had pecking tests with and without glass for scratching. All pecks at either substrate as well as ground scratches and vertical wing-shakes that occurred during the test were counted. On all days of pecking tests only the colour marked chick in the pair was tested. From day 10 until day 15 . we tested the chicks 30 minutes in order to see if the presence of the pecking substrates and the possibility to peck for a substantial period could elicit and control dustbathing behaviour. During the 30 min tests a glassplate $(30 \times 15 \mathrm{~cm})$ was always used. During these observations all vertical wing-shakes and scratches were recorded simultaneously in both chicks of each pair. Furthermore, in order to examine the association between a substrate and dustbathing behaviour, it was noted which substrate was pecked prior to any performance of vertical wing-shake and scratch (see Vesterga ard and Hog an 1992). Based on this criterion we hereafter refer to either peat or sand directed dustbathing or scratching according to the substrate that was pecked prior to the vertical wing-shake or scratch.

Dustbathing choice tests $(35 \mathrm{~min}$ ) were carried out on day 17 (after the pecking tests) and day 18 in a room adjacent to that of the home cages. Both chicks of a pair were tested at the same time for dustbathing (number of vertical wing-shakes) on yellow sand, peat and chicken food as described in Vesterga ard and Lisborg (1993). We also recorded dustbating on the wire floor. Birds which failed to perform vertical wing-shakes were retested the next day (i.e. day 18 or 19).

Experiment 2 was carried out in almost the same way as experiment 1 . The main difference was that half of the pairs were given 2 min pecking tests and the other half 10 min pecking tests on days 5-9, whereas they all were given 5 min pecking tests on days 3 and 4 . Also, we used brown construction sand in the boxes instead of yellow sand and peat. Additionally, the glassplates were only used day 10-15, and there were no pecking tests day 16 and 17. No dustbathing choice tests were made.

In both experiments all observations were carried out between 11.00 and $15.00 \mathrm{~h}$. and all tests and observations were made by direct observation and hand writing, the observer sitting one meter in front of the cages.

Statistics

Changes over time were tested by means of the Sign test or the Wilcoxon matched-pairs signed-ranks test, and correlations were tested by means of the Spearman rank correlation coefficient ( $\mathrm{S}$ i e ge l 1956). Differences between groups of birds were tested by means of the Mann-Whitney U-test or the Fisher exact probability test (Si g e l 1956). The binomial test and the Kolmogorov-Smirnov test were used to test for preferences between dust substrates (Siegel 1956). Regression analysis (SAS Institute Inc., 1989) was applied to reveal time 
variation in the frequency of pecking. and to examine the relationship between pecking and vertical wing-shaking. The regression analysis was performed with the "proc reg" procedure in the SAS (1989) statistical program package.

\section{Results}

\section{Experiment 1}

Pecking and scratching

Regression analysis was made on the log-transformed counts for pecking on days 3 to 9 , at peat and sand, respectively, and a significant daily increase of $64 \%$ was found for peat $(\mathrm{P}<0.0001)$ but not for sand (increase of $8.2 \%, \mathrm{P}=0.30$ ); see Fig. 1 . By day 9 , there was a clear preference for peat over sand (Binomial test, $\mathrm{N}=12, \mathrm{x}=2, \mathrm{P}<0.04$ ). Day 16 and 17 the amount of pecking was similar to that of day 9; not shown in the Figure. During the pecking tests day 3-9 the chicks usually swallowed the peat or sand after having pecked it. Scratching increased significantly until day 5-6 (days 3-4 compared to days $5+6$, Wilcoxon $\mathrm{T}=0$, $\mathrm{N}=11, \mathrm{P}<0.001 ;$ Figure 1). The increase was also significant for scratching directed at peat (Wilcoxon, $\mathrm{T}=0, \mathrm{~N}=11, \mathrm{P}<0.01$ ) and for scratching directed at sand alone (Wilcoxon $\mathrm{T}=1, \mathrm{~N}=7, \mathrm{P}<0.05$ ). Scratching then declined (days $5+6$ compared to days $8+9$, Wilcoxon, $\mathrm{T}=10.5$, $\mathrm{N}=11, \mathrm{P}<0.05)$. The amount of scratching on day 16 and 17 (not shown on Figure 1) was similar to the average level on day 5-7.

As a total for day 3-9 the birds scratched on average 9.9 and 11.1 times when the glass was on and off, respectively. Therefore, scratching was not facilitated by the glassplate.

During days 3-9, a significant positive correlation was found between the number of scratches directed at peat and the number of pecks at peat (Table 1; $\mathrm{r}_{\mathrm{s}}=0.92, \mathrm{P}<0.01$ ) and. similarly, for scratching directed at sand and pecks at sand $\left(r_{\mathrm{s}}=0.76 . \mathrm{P}<0.05\right)$. Scratching on days 3-9, however, was not significantly correlated with pecking day
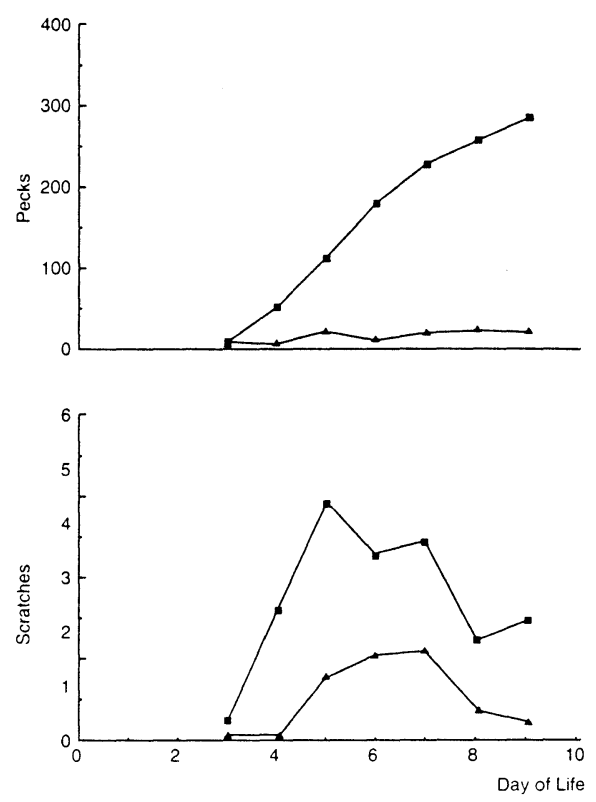

Fig. 1. Upper panel: Average number of pecks directed at peat $(\boldsymbol{\square})$ and sand $(\boldsymbol{\Delta})$ during the $5 \mathrm{~min}$ pecking tests on day 3-9 $(\mathrm{N}=11)$. Lower panel: Average number of scratches during the 5 min pecking tests on day 3-9, when pecking at either peat $(\boldsymbol{\square})$ or sand $(\boldsymbol{\Delta})$ on day 3-9 $(\mathrm{N}=11)$. $16+17$ (Table 1).

For sand directed behaviour, the early pecking (day 3-9) was significantly correlated with scratching on days $16+17\left(r_{s}=0.75, P<0.05\right)$, whereas for peat there was no such correlation (Table 1). During the pecking tests on day $16+17$, scratching directed at sand was significantly correlated with the pecks at sand $\left(r_{s}=0.81, P<0.05\right)$. whereas scratching directed at peat was not correlated with the pecks at peat (Table 1).

Finally, the early scratching (day 3-9) was not significantly correlated with the scratching on days $16+17\left(r_{s}=0.33\right.$ and $r_{s}=0.26$ for peat and sand directed behaviour, respectively. This result is not in the Table). 
Table 1

\begin{tabular}{|c|c|c|c|c|c|c|c|c|}
\hline & \multicolumn{4}{|c|}{ Pecking } & \multicolumn{4}{|c|}{ Vertical wing-shaking } \\
\hline & \multicolumn{2}{|c|}{ day 3-9 day } & \multicolumn{2}{|c|}{$16+17$} & \multicolumn{2}{|c|}{30 min test } & \multicolumn{2}{|c|}{ Choice test } \\
\hline & Peat & Sand & Peat & Sand & Peat & Sand & Peat & Sand \\
\hline \multicolumn{9}{|l|}{ Scratching: } \\
\hline Peat day 3-9 & $.92 * *$ & & -.11 & & .48 & & .43 & \\
\hline Sand day 3-9 & & $.76 *$ & & .48 & & .22 & & .08 \\
\hline Peat day $16+17$ & .24 & & .30 & & -.05 & & -.11 & \\
\hline Sand day $16+17$ & & $.75 *$ & & $81^{*}$ & & $.83 * *$ & & $67 *$ \\
\hline
\end{tabular}

Table 1. Spearman rank correlations between scratching (day 3-9 and 16+17) and 1) pecking (day 3-9 and day 16+17) and 2) vertical wing-shakes (during 30 min tests and choice tests) according to ty pe of substrate that was pecking or pecked while scratching during pecking tests. $N=11$ for all correlations. Significant correlations are indicated as follows: $*=\mathrm{P}<0.05 . * *=\mathrm{P}<0.01$ (two-lailed).

Only very few vertical wing-shakes appeared during the 5 min pecking tests and they were not further analyzed.

Dustbathing during $30 \mathrm{~min}$ pecking tests: Time trends. amounts and preference

After the initial pecking and scratching at the start of the 30 min pecking and dustbathing tests vertical wing-shaking appeared in succession in most chicks and increased significantly in number between the first and the second 5 min period (Wilcoxon, $\mathrm{N}=6, \mathrm{~T}=0, \mathrm{P}<0.05$ ). Thereafter there were no significant differences between 5 min periods. Throughout the tests the chicks almost invariably pecked either peat or sand before performing any vertical wing-shake on the glassplate. For some chicks it seemed that the access to the pecking substrates elicited and controlled dustbathing behaviour, whereas other chicks made very little or no vertical wingshaking during the tests. The mean number of vertical wing-shakes for all days combined (focal chicks) was $79.2 \pm 21.5$. The preference for peat for dustbathing was

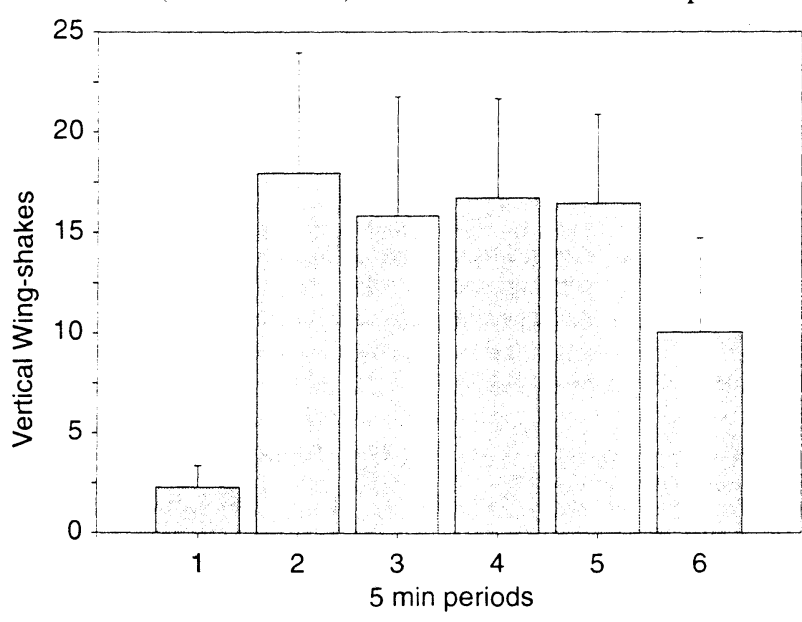

Fig. 2. Mean numbers $(+$ SEM) of vertical wing-shakes over the consecutive 5 min periods of the six 30 min pecking and dustbathing tests. Means $(+\mathrm{SEM})$ are per chick $(\mathrm{N}=11)$ for the sum of all 6 days. not significant (Binomial test, $\mathrm{P}>0.10)$. We also tested the preference based on the number of vertical wingshakes made by each pair, but again, the result was not significant $(P>0.05)$. All these average values were similar for the non-focal chicks, and therefore the average values for pairs are presented in Table 2. There was no significant correlation between total vertical wingshaking directed at peat and sand between chicks within pairs $\left(r_{s}=0.46, P>0.05\right.$; Table 2) 
Table 2

\begin{tabular}{|c|c|c|c|c|c|c|}
\hline & \multicolumn{2}{|c|}{ 30-min tests (Exp.1) } & \multicolumn{2}{|c|}{ Choice tests (Exp.1) } & \multicolumn{2}{|c|}{ Experiment 2 (Focal chicks) } \\
\hline & Focal (SEM) & Pair (SEM) & Focal (SEM) & Pair (SE) & $\begin{array}{l}\text { 2-min group } \\
(\text { SEM) }\end{array}$ & $\begin{array}{l}\text { 10-min group } \\
(\mathrm{SEM})\end{array}$ \\
\hline Peat & $54.8 \quad(17.8)$ & 57.0 (14.7) & $6.2(2.9)$ & $7.6(2.0)$ & - & - \\
\hline Sand & $24.4 \quad(8.0)$ & $23.3 \quad(5.5)$ & 3.7 (2.6) & $5.3(3.1)$ & $11.6(5.6)$ & $21.9(7.9)$ \\
\hline Subtotal & $79.2 \quad(21.5)$ & $80.3 \quad(16.5)$ & $10.0 \quad(3.8)$ & $12.8(3.0)$ & - & - \\
\hline Wire & $0.73 \quad(0.5)$ & $2.5 \quad(1.1)$ & $12.5 \quad(5.6)$ & 10.8 & - & - \\
\hline Total & $79.9 \quad(21.6)$ & $82.9 \quad(1.1)$ & $22.5 \quad(6.6)$ & $23.7(5.6)$ & $11.6(5.6)$ & $21.9(7.9)$ \\
\hline
\end{tabular}

Table 2. Vertical wing-shaking during the 30-min tests, the dust-bathing choice tests and during the dustbathing tests in Experiment 2. None of the chicks dustbathed in the food during the dustbathing-choice tests and therefore food is not included in the Table. "Pair" refers to the average number of vertical wing-shakes in the pair.

Pecking (day 3-9) and dustbathing (day 10-15): overall analysis of association

First we made an overall analysis to investigate if early pecking on days 3-9 had influenced the later dustbathing as expressed by the numbers of vertical wing-shakes on days 10-15. To do that, the total counts of pecks and vertical wing-shakes at both peat and sand were averaged for the respective periods for each focal bird and used for the analysis. The variation in average vertical wing-shaking was sought explained by the average early pecking activity. To account for the different vertical wing-shaking activity levels expressed by the chicks, a 0,1 dummy variable ( 3 minus 1 ) for three groups as included in the model (the group sizes were 4, 3 and 4, and the rates of pecking at peat for the three groups were 62,51 and 32 , respectively). This implies a model with different intercepts but common slope parameter for the pecking activity. The average counts for wing-shaking during days $10-15$ were $1.8+3.4,13.6+9.0$ and $24.2+8.2$ for groups 1,2 and 3 , respectively. The regression result indicated that early pecking affects (or is associated with) later dustbathing activity. The estimated parameter for pecking was $0.065(\mathrm{P}<0.01)$. This corresponds to an increase of 6.5 vertical wing-shakes for every increase of 100 pecks.

\section{Dustbathing choice tests}

Among the substrates presented for dustbathing (i.e. ignoring the vertical wing-shakes performed on the wire floor) 5 focal chicks performed most of their vertical wing-shakes in the peat. while only 1 performed most in the sand; no chicks entered the food tray to dustbathe (Table 2. central section). The other 5 chicks (one of the 12 focal chicks had died) did not dustbathe in any of the substrates. Nine focal chicks dustbathed on the wire mesh, and 2 did not dustbathe at all during the tests; all the mean values appear from Table 2. central section. Similar results were found for the non-focal chicks, but there was no significant correlation between the number of vertical wing-shakes in the substrates by the focal chicks and the nonfocal chicks $\left(r_{s}=0.022, P>0.10\right)$. Based on the literature (see Vesterga ard 1994) we assumed that the food would be least attractive and peat most attractive for dustbathing, and a test based on the number of vertical wing-shakes made by each pair revealed that the substrates were indeed differently preferred as expected (Kolmogorov-Smirnov one-sample test, $\mathrm{N}=10, \mathrm{P}<0.05$ ). The result for the focal chicks alone, however, was not significant $(\mathrm{P}>$ 0.20 ). Finally, for the focal chicks a significant positive correlation was found between the total number of vertical wing-shakes in the substrates (during the choice tests) and the total number of vertical wing-shakes during the 30 min pecking and dustbathing tests $\left(r_{s}=0.68\right.$, $\mathrm{P}<0.05$ ). i.e., the amounts of dustbathing during the two tests were correlated. 
Table 3

\begin{tabular}{|lcccccccccc|}
\hline $\begin{array}{l}\text { Day } \\
\text { (pecking) }\end{array}$ & 3 & 4 & 5 & 6 & 7 & 8 & 9 & 16 & 17 & $3-9$ \\
\hline Peat & $.64^{*}$ & .57 & $.63 *$ & .30 & .29 & .43 & -.07 & -.07 & -.47 & -.44 \\
Sand & $.64^{*}$ & .50 & .31 & .53 & .48 & .43 & $.73 *$ & $.81^{*}$ & $.68^{*}$ & .50 \\
\hline
\end{tabular}

Table 3. Spearman rank correlations between number of pecks during the 5 min pecking tests and number of vertical wingshakes during the six 30 min tests day 10-15. "Peat" are the correlations between vertical wing-shakes while pecking at peat (i.e. vertical wing-shakes directed towards peat) and number of pecks at peat during the 5 min pecking tests. ..Sand" are the correlations between vertical wing-shakes while pecking at sand (i.e. vertical wing-shakes directed towards sand) and number of pecks at sand during the 5 min pecking tests. * indicates significant correlations $(P<0.05$. 1 wo-tailed).

\section{Correlation between pecking and dustbathing ( $30 \mathrm{~min}$ tests)}

The numbers of vertical wing-shakes during the $30 \mathrm{~min}$ tests were examined for correlation with pecking for each day of pecking tests (Table 3 ). For the correlations between vertical wing-shakes directed at peat (day 10-15) and pecks at peat during the 5 min pecking tests a significant positive correlation was found day 3 and $5\left(r_{s}=0.64, P<0.05\right)$, but thereafter the coefficients became smaller and non-significant. A major change happened after day 8 where the coefficients became negative. For the correlations between vertical wing-shakes directed at sand (day 10-15) and pecks during the 5 min pecking tests a similar trend was found until day 8 with a high and significant positive correlation with pecking during day $3\left(\mathrm{r}_{\mathrm{s}}=0.64, \mathrm{P}<0.05\right)$. Thereafter, however, a somewhat different trend was found, because the highest positive (and significant) values were found on day $16\left(\mathrm{r}_{\mathrm{s}}=0.81\right.$, $\mathrm{P}<0.05), 9$ and 17 . None the less, again a change seemed to happen after day 8 , because by day 9 the correlations became significant again $\left(r_{s}=0.73, P<0.05\right)$.

Table 4

\begin{tabular}{|lccccccccc|}
\hline Day & 3 & 4 & 5 & 6 & 7 & 8 & 9 & 16 & 17 \\
\hline Peat & $.77^{*}$ & .39 & .37 & .49 & .18 & .07 & .06 & -.13 & -.16 \\
Sand & $.98^{* *}$ & .54 & .00 & .19 & -.08 & -.28 & .10 & .39 & .48 \\
All & -.17 & .60 & $.63^{*}$ & .61 & $.67 *$ & .51 & .40 & -.13 & -.33 \\
\hline
\end{tabular}

Table 4. Spearman rank correlations between number of vertical wing-shakes during the dustbathing choice test and pecks during the $5 \mathrm{~min}$ pecking tests. "Peat" are the correlations between vertical wing-shaking in peat and pecks at peat during 5 min pecking tests. "Sand" are the correlations between vertical wingsshakes in sand and pecks at sand during 5 min pecking tests. "All" are the correlations between all vertical wing-shakes including those that were performed on the wire floor and all pecking (at peal+sand) during 5 min pecking tests. $N=11$ for all correlations. Significant correlations are indicated as follows: $*=\mathrm{P}<0.05, * *=\mathrm{P}<0.01$ (two-tailed).

Correlation between pecking and dustbathing (dustbathing choice test)

The Spearman rank correlations between vertical wing-shakes during the dustbathing choice tests and pecking during the 5 min tests appear from Table 4 . For dustbathing in peat the correlation with pecking at peat was strongest for pecks on day $3\left(\mathrm{r}_{\mathrm{s}}=0.77\right.$, $\mathrm{P}<0.05)$ and then the correlation coefficients generally decreased with age. For the correlations between vertical wing-shaking in sand and pecking at sand a similar trend was found with a very high value for day $3\left(r_{s}=0.98, P<0.05\right)$. Finally, the correlations between all vertical wing-shakes (including those that were performed on the wire floor) and pecking during the 5 min pecking tests (at peat + sand), were first low, then increasing and finally decreased with day of pecking test. Significant positive correlations were found for day 5 and $7\left(r_{s}=0.63\right.$ and 0.67 , respectively; $\left.P<0.05\right)$. Again, as with the 30 min 
tests, combining pecks for day 3-9 failed to increase the strength of correlation (not presented in the Table).

\section{Correlation between scratching and dustbathing}

The early scratching (day 3-9) directed at each of the substrates (peat or sand) was examined for correlation with the number of vertical wing-shakes on day 10-15 (Table 1). The correlations, however, were not significant. Similarly the correlations between the early scratching (day 3-9) and the number of vertical wing-shakes during the choice tests were non-significant.

Later on the picture was different (Table 1) because scratching while pecking at sand on day $16+17$ was significantly correlated with the number of vertical wing-shakes directed at sand during the 30 min pecking and dustbathing tests day $10-15\left(r_{s}=0.83, N=11, P<0.01\right)$. However, for the corresponding peat directed behaviour there was no significant correlation between scratching day 16-17 and the number of vertical wing-shakes day 10-15. Similarly scratching on day $16+17$ was significantly correlated with the number of vertical wingshakes in sand during the dustbathing choice tests $\left(r_{s}=0.67 ; P<0.05\right)$, whereas, again, there was no such correlation for the peat directed behaviour.

\section{Experiment 2}

The total pecking rates for day 3-9 were $429 \pm 224$ (mean + SEM) and $491 \pm 107$ pecks for the $10 \mathrm{~min}$ and the $2 \mathrm{~min}$ pecking group, respectively, and this difference was significant (Mann-Whitney U-test, $\mathrm{P}<0.01$ ). Similarly, for scratching the rate was higher for the chicks on the 10 min treatment, but the difference only approached significance $(\mathrm{P}<0.07)$. More birds on the 10 min pecking treatment as compared to the 2 min treatment performed vertical wing-shaking during the first 30 min pecking test on day 10 (Fisher exact probability test, $\mathrm{P}<0.05$ ). Furthermore, for all days (day 10-15) combined there was on average more vertical wing-shakes in the $10 \mathrm{~min}$ than in the $2 \mathrm{~min}$ pecking group (Table 2). This difference, however, only approached significance $(\mathrm{P}<0.10)$.

\section{Discussion}

The analysis of pecking showed that young chicks seek information about dust up to at least day 9 of life with increasing intensity of pecking directed at a prefunctionally preferred substrate, i.e. peat. Furthermore, the regression analysis indicated that the amount of dustbathing on days 10-15 can be explained by the overall pecking activity on days 3-9.

The correlation data strongly suggest that the pecking at peat and/or sand during day 3 correlates best with later dustbathing directed towards the same substrate(s). so that the correlation gradually becomes weaker with age (day of pecking test). This was true not only for dustbathing during the 30 min pecking tests but also for dustbathing during choice test for which the strongest correlations with pecking during day 3 were found. The only exception to this general picture was that dustbathing directed towards sand during the 30 min pecking tests (but not during the choice tests) was better correlated with pecking at sand during the 5 min pecking tests on day 9,16 (especially) and 17. Interestingly, the total number of vertical wing-shakes (i.e. including those performed on wire floor) during the choice tests was more weakly correlated with the early pecking during 5 min pecking tests, and for the pecking on day 3 the correlation was low and negative. This indicates that the early pecking is related to the development of dust perception rather than to the ability to perform dustbathing behaviour per se (see also Vesterg a ard et al. 1990). Nevertheless, these correlations were significant day 5 and 7 , so it may be that the amount of early pecking 
is related to how easily dustbathing is released, even on a wire mesh floor. Interestingly, although the food was available at all time for pecking in the home cage, it was ignored as a dustbathing substrate during the dustbathing choice tests. It is also interesting that the peat and sand was swallowed during the early pecking tests. Food was also present during the pecking tests but not pecked at during them. Possibly the substrates for dustbathing have to be identified as "non-food" and this can only happen after swallowing (see V e sterga a r d 1994. p. 120-124). The indication of a preference for peat is in accordance with other studies (Petherick and Duncan 1989; Liere and Siard 1991). The association between the very early pecking and dustbathing may indicate that the very first pecking experience with dustbathing substrates is of special significance for the development of an association between a substrate and dustbathing behaviour. On the other hand it could be that the preference for pecking a substrate at an early age is related prefunctionally to the preference for that substrate for dustbathing. None the less, our results from experiment 2, support the first explanation because more pecking (day 5-9) resulted in more dustbathing later on. The results from experiment 2 also confirm those of earlier studies in Bobwhite quail (Colinus virginianus. ) which showed that the early possibility to peck, mandibulate and swallow dust (sifted dry earth), strongly facilitated the performance of dustbathing on day 7 when full access to dust was allowed (Borchelt and Overmann 1975).

In our study pecking during the 30 min dustbathing tests obviously lead to dustbathing (vertical wing-shaking): it was not necessary for the chicks to enter and actually ,bathe" in the dust. This result, therefore, indicates that the access to a substrate for pecking could elicit and maybe control dustbathing. The reason that some chicks dustbathed very little was possibly that they pecked at a low rate during the early pecking tests (day 3-9) and consequently failed to gain enough experience for an association between the substrates and dustbathing to develop. The results of experiment 2 support this view. However, the chicks generally dustbathed little in experiment 2 . possibly because we used white paper below the wire. whereas in experiment 1 we used brown paper that may look more like a dustbathing substrate (visual stimuli are now known to be significant; Petherick and Duncan 1989). Another problem in experiment 2 was that all pairs were given 5 min tests on day 3 , and this may have tended to reduce the difference in dustbathing performance between the 10 and the 2 min pecking groups [because day 3 was the most significant day of pecking for the association to (later) dustbathing to be established].

The correlation between pecking and ground scratching at the early stage (day 3-9 in this study), and its disappearance later (in the case of the peat directed behaviour). has previously been documented in the red junglefowl and discussed in relation to the development of food recognition ( $\mathrm{Hog}$ a n 1971: 1988). Pecking and ground scratching possibly are organized prefunctionally as a unit ( $\mathrm{Hog}$ an 1988), and in our study the association between them may have disappeared in the case of peat directed behaviour, because of lack of appropriate functional experience (the chicks could not enter the box to scratch the substrates; see Hogan 1988). However. in our study scratching directed at sand remained to be significantly associated with pecking at sand and (later on) dustbathing directed towards sand. Possibly the association became established during the 30 min tests day $10-15$, because the early scratching (day 3-9) was not correlated with dustbathing. The role of scratching in the development of dust recognition, therefore may depend on the type of stimulus. Sanotra et al. (1995) found that factors that controlled scratching in young chicks were different from those that controlled dustbathing.

In conclusion, our results indicate that there is a sensitive period with a peak around day 3 for the development of the perceptual mechanism of the dustbathing behaviour system and that the development is related to pecking at the substrates. We do not know, however, the 
significance of pecking at dust day 1 and 2 . Also, the present study is mainly based on correlations in chicks on the same treatment, and more experimental studies, in which pecking experience is controlled at various ages, are needed to reveal more clearly, the influence of early pecking and scratching experience on the development of dust perception in fowl.

\section{Zobání a hrabání ve vývoji percepce substrátu k popelení u kuřat po vylíhnutí}

Sledovali jsme, zda raná zkušenost zobání a hrabání může u kuřat ovlivnit jejich popelení v pozdějším životě. Zobání $\mathrm{v}$ substrátu bylo sledováno u párů kuřat chovaných v drátěných klecích, jimž jsme prezentovali rašelinu a žlutý písek jako substráty $\mathrm{k}$ popelení $\mathrm{v}$ krabičkách $3 \times 3 \mathrm{~cm}$. V prvním pokusu ( 12 párủ kuřat), jsme prováděli 5 min testy mezi od 3. do 9 . dne, dále v 16. a 17. dnu. Mezi 10. a 15. dnem mohla kuřat v substrátu zobat po dobu 30 minut, aby se u nich vyvolalo popelení na skleněné plotně. Konečně, preferenční test, $v$ němž byl kuřatům umožněn plný príistup $\mathrm{k}$ popelišti a oběma substrátům, byl proveden v 16.-19. dnu po vylíhnutí. Ve druhém pokusu mělo 8 párů kuřat možnost 2 min zobání, 8 párů 10 min zobání s použitím písku mezi $5 .-9$. dnem. Všechny páry měly možnost 5 min zobání ve 3. a 4. dnu. Mezi 10. a 15. dnem pak byla všechna kuřata testována na popelení, jako v pokusu 1 . V prvém pokusu frekvence zobání stoupala od 3. do 9. dne a kuřata preferovala rašelinu před pískem jako substrát k zobání. Frekvence zobání v jednom anebo obou substrátech byla korelována s pozdějším výskytem popelení v nich. Byla nalezena pozitivní a signifikantní korelace mezi zobáním 3. dne a popelením na skleněné plotýnce (10.-15. dne), podobně jako mezi popelením v substrátech v preferenčních testech. Hrabání během 5 min testủ bylo pozitivně korelováno se zobáním $s$ výjimkou hrabání v testech $\mathrm{s}$ rašelinou 16. a 17. dne. Hrabání v těchto dnech bylo pozitivně korelováno s popelením v písku (30 min test), a v preferenčních testech, když kuřata $v$ těchto dnech zobala $v$ písku. Ve druhém pokusu kuřata s největší zkušeností zobání se popelila více v 30 min testu mezi 10. a 15. dnem. Z výsledkủ tedy vyplývá, že zobání v prachových substrátech v raném údobí po vylíhnutí (3.-5. den) mělo vztah k pozdejjšímu popelení a může být významné pro vývoj percepce substrátủ k popelení u mladých kuřat, zatímco hrabání doprovázející zobání v písku počalo mít vztah k popelení až po 10.-15. dnu života.

\section{Acknowledgements}

During this study Eva Baranyiová was supported by the Danish Animal Welfare Association. We thank Linda S. Olesen and Christina M. Nygatard for assistance with the observations, and Lartey Lawson for help with the statistical analysis.

\section{References}

BORCHELT. P. L.. DUNCAN. L. 1974: Dustbathing and feather lipid in bobwhite quail (Colinus virginiunus). Condor. 76:+71-472

BORCHELT. P. L.. EYER. J.. McHENRY. D. S. Jr. 1973: Dustbathing in bobw hite quail (Colinus virginianus) as a function of dust deprivation. Behav. Biol. 8:109-114

BORCHELT. P. L.. OVERMANN. S. R. 1975. Development of dustbathing in bobwhite quail. II. Effects of early pecking experiences. Devel. Psychobiol. 8:+17-423

HOGAN. J.A. 1971: The development of a hunger system in young chicks. Behaviour 39:128-201.

HOGAN. J. A. 1988: Cause and function in the development of a behavior system. In: Handbook of Behavioral Biology, vol. 9 (Ed. by E.M. Blass). pp. 63-106. New York: Plenum Press.

HOGAN. J. A.. HONRADO. G. I.. VESTERGAARD, K. S. 1991: Development of a behavior system: Dustbathing in the Burmese red junglefowl (Gallus gallus spadiceus): II. Internal factors. J. Comp. Psychol. 105, 269-273. 
KRUIJT, J. P. 1964: Ontogeny of social behaviour in Burmese red junglefowl (Gallus gallus spadiceus). Behav. Suppl. 12. $201 \mathrm{p}$.

LIERE, D.W.. van, SIARD, N. 1991: Towards an understanding of litter bathing quality in hens. In: Proceedings of a Symposium of the Society for Veterinary Ethology: Applied Animal Behaviour: Past. Present and Future (Ed. by M. C. Appleby. R. I. Horrell, J. C. Petherick. S. M. Rutter), pp. 132-133. Potters Bar. Herts: Universities Federation for Animal Welfare.

PETHERICK. J. C.. DUNCAN. I. J. H. 1989: Behaviour of young domestic fowl directed towards different substrates. Br. Poult. Sci. 30:229-238

PETHERICK. J. C.. SEAWRIGHT, E., WADDINGTON. D..DUNCAN. I. J. H., MURPHY. L. B. 1995: The role of preception in the causation of dustbathing behaviour in domestic fowl. Anim. Behav. 49:1521-1530

SANOTRA. G. S.. VESTERGAARD, K. S., AGGER, J. F.. LAWSON, L. G. 1995: The relative preferences for feathers, straw, wond-shavings and sand for dustbathing. pecking and scratching in domestic chicks. Appl. Anim. Behav. Sci. 43:263-277

SAS Institute Inc. 1989: SAS/STAT User`s Guide, version 6. 4th edition. vol. 2. Gary, NC: SAS Institute Inc.. 846 p. SIEGEL. S. 1956: Nonparametric Statistics for the Behavioral Sciences. Tokyo: McGraw-Hill Kogakusha.

VESTERGAARD. K. 1982: Dustbathing in the domestic fowl. Diurnal rhythm and dust deprivation. Appl. Anim. Ethol. 8:487-495

VESTERGAARD. K.. HOGAN. J. A., KRUIJT. J. P. 1990: The development of a behavior system: dustbathing in the Burmese red junglefow. I. The influence of the rearing environment on the organization of dustbathing. Behaviour 112: 99-116

VESTERGAARD. K.. HOGAN. J. A. 1992: The development of a behavior system: dustbathing in the Burmese red junglefowl. III. Effects of experience on stimulus preference. Behaviour, 121:15-230

VESTERGAARD. K. S.. LISBORG, L. 1993: A model of feather pecking development which relates to dustbathing in the fowl. Behaviour 126:89-106

VESTERGAARD. K. S. 1994: Dustbathing and its relation to feather pecking in the fowl: Motivational and developmental aspects. Dissertation. The Royal Veterinary and Agricultural University. Copenhagen, $150 \mathrm{p}$. 